\title{
Trade in Value Added (TiVA) in EU New Member States (EU NMS)
}

\section{Ines Kersan-Škabić}

Juraj Dobrila University of Pula, Faculty of Economics and Tourism "Dr. Mijo Mirković", Pula, Croatia

ikersan@unipu.hr
CroEconSur

Vol. 19

No. 2

December 2017

pp. 105-133

Received: March 7, 2017

Accepted: November 6, 2017

Review Article

doi:10.15179/ces.19.2.4

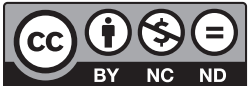

\section{Abstract}

Contemporary trade analysis indicates the necessity of calculating trade in value added (TiVA) which is created through global value chains (GVCs). This paper aims to determine the characteristics and importance of GVC trade in the EU new member states (EU NMS) with special emphasis placed on the industry level. The results demonstrate different levels of GVC participation of the EU NMS, where Hungary is the most integrated country and Croatia the least integrated. Regional GVCs exist because a huge part of value added (VA) comes from EU member states, as in gross export as well as in final demand (Europe as a hub). The most important source countries are Germany and Italy and there is also evidence of geographical and historical relations between the countries. The domination of backward participation has been found in the analysis made 
on the industrial level, i.e. the EU NMS are highly dependent on the import of intermediates for the production and export of final products.

Strong interconnections between imports of intermediate products and exports of final products have been found in the manufacture of computers, electronics and optical products; manufacture of wood, paper, printing and reproduction. This research has contributed to the scarce literature concerning GVC (TiVA) in EU NMS and has opened up new possibilities for further research and analysis.

Keywords: trade in value-added, TiVA, global value chain, GVC, EU new member states, EU NMS, export

JEL classification: F12, F14, F15

\section{Introduction ${ }^{1}$}

The process of trade liberalization, as well as the development of infrastructure, information, and communication technology have stimulated and accelerated the development of global value chains (GVCs). They resulted from firm heterogeneity, multinational companies' (MNC) activities, economics of scale and increasing returns (Friedman, 2005, Melitz, 2003, Krugman, 1979). They contributed to the production fragmentation across countries, to the development of trade in "tasks" but also to the increase of efficiency and firm competitiveness.

Trade analysis has mainly been provided through traditional approaches extracting data from national (or international) balance of payments statistics. Traditional approaches to trade statistics do not fully reflect the picture of how far the economies have become interconnected and interdependent. In a more globalized economy, there is a need to propose and systematize new measurement tools that will be appropriate for analysis of inter-industrial trade in intermediate inputs. This trade has increased as GVCs allow less advanced countries to import 1 An earlier version of this paper was presented at the $1^{\text {st }}$ International Conference "Smart Ideas and a New Concept of Economic Regeneration in Europe (SINCERE)”, held in Dubrovnik, Croatia, from September 28-October 1, 2016. 
technology, industrial norms and market access from the lead firms. Firms in low-income countries can leap-frog the industrialization ladder by specializing in some of the tasks required for the manufacturing and export of sophisticated products. As a result, the export structure may not anymore reflect the relative situation of the exporting country with respect to the technology frontier (Ferrarini and Scaramozzino, 2011).

GVCs have made the analysis of international trade more complex and the statistics on gross exports and imports inadequate to measure the real flows of value added between the economies (Javorsek and Camacho, 2015). Broader frameworks for calculating the foreign and domestic content in exports have been suggested by Koopman et al. (2010), Johnson and Noguera (2012), Stehrer, Foster and de Vries (2012), and Koopman, Wang, and Wei (2014). The idea of GVC (value added, VA) trade is to separately calculate the domestic VA (which is produced in the home economy) and also to consider the foreign VA in exported goods. In that way, trade structure and value will reflect the real contribution of every country and avoid the over-estimation of foreign trade.

The trade statistics indicate an increasing trend of trade created in GVCs thanks to the high level of trade and financial openness in developed and emerging markets. Today, more than half of world's manufactured imports are intermediate goods (primary goods, parts and components, and semi-finished products), and more than 70 percent of world's services imports are intermediate services (De Backer and Miroudot, 2013).

The topic of GVC trade has mainly been researched on the East Asian countries as they are the most attractive location for the production of plenty of products (and services) and they participate in many production chains (WTO and IDEJETRO, 2011). Research on the GVC contribution to total trade in other parts of the world is scarce but it is believed that it is important to find out the real value of export in the EU NMS as they are also attractive locations for GVC (or the European value chain) enlargement. The aim of this paper is to calculate 
the importance of value-added trade in EU NMS in order to obtain accurate/ real data about their participation in trade. Their GVC participation index and the GVC position index will be calculated. Also, focus will be placed on the industrial level to find out the importance of trade in VA in every particular sector and how it contributed to the export growth (competitiveness). An analysis has been performed based on the World Trade Organization (WTO) and United Nations Conference on Trade and Development (UNCTAD) source of data, applying statistical and econometric tools.

The novelty of this research is twofold: (1) in focusing on the EU NMS and on the deep analysis of their participation in GVCs; and (2) in the emphasis placed on the characteristics of sectors' participation in GVCs and their influence on export performance.

The rest of the paper is organized as follows: the second section comprises the characteristics of GVC trade and provides an overview of existing research. The third section presents the research, followed by the conclusion.

\section{Literature Review}

A value chain includes a full range of activities that firms undertake to bring a product or a service from its conception to its end use by final consumers. It refers to the spreading of production across countries, continents and the world. The well-known tag 'Made in...' (a particular country) is not (or is very rarely) connected with just one country since the products and services are usually produced in many countries from their initial stage of production until the final product (or service), allowing us to discuss the 'Made in the world' tag.

The development of GVCs has an important and inevitable role in the global trade flows. "As part of global production chains, products at different stages of value added may be imported and re-exported multiple times, increasing the size of reported exports and imports relative to global and national value added. 
In advanced countries, this effect is reinforced by the fact that imports can contain a significant portion of inputs-including intellectual property, branddevelopment, etc.- - originally sourced at home; in developing countries, imports of components and machines are crucial vehicles for absorption of technologies" (World Economic Forum, 2012: 4).

The term GVC has appeared in international business literature in the last 15 years and is derived from the global commodity chain. Gereffi and FernandezStark (2011) give an overview of GVC development and its name changes. GVCs are at the center of Porter's research who indicates the importance of firm competitiveness (Porter, 1990). Countries tend to specialize in specific business functions rather than specific industries.

Trade in value added (TiVA) measures only the amount of value added by a particular country in the production of a particular exportable product and will be recoded as exports of this country (not the total value of that product if it was partially produced abroad and imported).

In the trade reports there are plenty of data for goods and services trade, but they refer to the total trade. Measurement of GVC trade is more complicated due to limited data availability.

It remains important to keep in mind that traditional classifications-based on imported and exported goods (shares of final products, intermediate goods etc.) - can be greatly misleading when trade takes place in GVCs, where what is actually traded are the tasks and not the products.

Daudin, Rifflart and Schweisguth (2011) and Hummels, Ishii and Yi (2001) were the first researchers who dealt with the estimation of trade in value added. Escaith (2015) explains the implementation of national and international inputoutput tables to establish direct and indirect linkages between countries and sectors (originally developed by Leontief). 
Even though authors usually believe that GVCs operate globally, the truth is that they are 'regional' in nature and focused on three hubs-North America, Europe, and East Asia. The first two regions are primarily centers of demand while the third region is the center of supply, although this may be subject to change as China moves to reform its economy toward a more consumer-driven demand growth. The reasons behind this regionalization can be found in transportation costs, distance, communication, quality of infrastructure, but also in regional trade agreements (RTAs) reached through the rules of origin and cumulating provisions (Stephenson, 2013).

At the global level, the countries of East and Southeast Asia are leading in the developing world in terms of integration into GVC (UNCTAD, 2013a). "China has become the world's factory with transnational companies relocating their production platform in the country" (Javorsek and Camacho, 2015: 3). Kwon and Ryou (2015) found progressive development of vertical specialization in the major exporting industries in China, Japan, and Korea. This indicates the strengthening ability of East Asia to create value added, in contrast to advanced countries in Europe and North America.

In the EU, the pushing factors behind GVC growth involved EU enlargement to the countries of Central and East Europe (which increased the internal market by over 100 million people-consumers) and the creation of a monetary union in which the majority of EU member states participate (currently 19 out of 28).

Leitner and Stehrer (2014) determined that vertical specialization intensified in most of the EU NMS and that export growth is beneficial to performance. Stronger participation in global production processes is performance-enhancing. Their results indicate that export growth and the degree of vertical specialization tend to reinforce each other.

GVCs are an important determinant not just of trade but also of employment and productivity. Timmer et al. (2013) analyze the effect of increasing production fragmentation on jobs in the EU-27. The results point to the fact that between 
1995 and 2008, GVC-related manufacturing jobs dropped by 1.8 million due to heavy job losses in the manufacturing sector and the agricultural sector. On the other hand, developments in the service sector, which experienced an increase in GVC-related jobs by 3.5 million, more than compensated for the losses in the manufacturing sector. Jiang and Milberg (2013) researched the employment effects of a country's participation in GVCs. Their analysis shows that in 2009 alone, GVC trade generated a total demand for about 88 million jobs, half of which were the result of vertical specialization. Moreover, they point to non-negligible cross-country differences and highlight that in 2009 vertical specialization created the lowest demand for jobs in small economies like Estonia, Malta, Latvia or Cyprus.

Van Ark et al. (2013) were focused on identifying the labor productivity effect of production activities for the global market in the EU-27. They demonstrate that such production-for-the-global-market activities are important sources of labor productivity growth and account for a quarter of labor productivity growth in Europe.

Amador, Cappariello and Stehrer (2015) determined that in 2011, considering the eurozone members (taken as a whole), GVCs were as important as in China and more important than in the US and Japan. The high relevance of GVCs in the eurozone, measured by the share of foreign value added in exports, is accompanied by their comparatively stronger resilience in the face of the trade collapse.

Fronczek (2016) focused her study on the EU-15. The comparison between gross- and value-added terms indicate that the EU-15's share in global export measured on value-added basis was smaller when compared to the conventional approach. She also emphasized the worsening position of EU-15 member states among the top 20 most important exporters (in 1995, nine EU-15 member states were featured in the top 20, while in 2011 only six remained and most of them ranked lower than in 1995). 
Olczyk and Kordalska (2017) researched the impact of selected determinants on both value-added exports and gross exports for seven Central and Eastern Europe (CEE) economies for the 1995-2011 period, based on 13 manufacturing subsectors. They found a decrease in domestic value added, especially in hightech industries. Their results indicate that labor productivity and highly skilled employees have a greater impact on generating domestic value added. CEE countries do not achieve comparative advantages of a capital-intensive nature.

Koopman, Wang and Wei (2014) developed a conceptual framework for calculating a country's gross exports by its various value-added and doublecounted components and they focused their research on the comparison of revealed comparative advantage (RCA) of gross exports and value-added exports. They found some sectors that have a comparative advantage according to gross value, demonstrating at the same time a comparative disadvantage when calculated based on value-added terms. So the data and results lead to different conclusions.

The crisis period exerts an impact on the drop of international trade and by using structural decomposition analysis, Nagengast and Stehrer (2015) show great collapse in value-added trade. The changes in vertical specialization accounted for almost half of the great trade collapse. The important finding is also that the decline in aggregate demand accounted for roughly a quarter of the decline in value-added exports.

\section{Research}

\subsection{Methodology and Data}

There is no internationally agreed methodological framework for measuring trade on a value-added basis, as international guidelines on measuring trade focus on gross values of goods and services. Furthermore, it is not possible to measure trade on a value-added basis directly using official trade statistics. 
More complete, and in some way, official databases have been created by the WTO and the Organization for Economic Co-operation and Development (OECD) - Trade in value added (TiVA) in 2013 and in 2015². International input-output (II-O) tables enable the origin and the use of intermediate goods and services to be identified by country and sector. II-O tables provide relevant assets for the analysis of trade verticality as they make clear the inter-sectoral nature of the modern production processes and their international connections. Thus, they take into account all backward linkages between countries and sectors present in the table, and they capture the value of imported inputs used directly and indirectly (at all stages of a country's production) in the manufacturing of exported goods (WTO and IDE-JETRO, 2011; De Backer and Miroudot, 2012).

This report covers the years 1995, 2000, 2005, and 2008 to 2011. This database will be used in the research. ${ }^{3}$

The most commonly used indicators that form the basis of gross export (GE) disaggregation in value-added terms (OECD, 2013):

1. Domestic value added embodied in gross exports (DVA): refers to the value added generated by the domestic economy in the production (direct and indirect) of goods and services for export. It includes the value added embodied in all exported goods and services produced by national industries, including the domestic value added that was previously exported and re-imported to be used in production of intermediates.

2 The latest report presents indicators for 61 economies and is broken down into 34 industrial sectors (16 manufacturing and 14 service sectors). It includes the decomposition of gross exports by industry into their domestic and foreign contents; the services content of gross exports by exporting industry (broken down by foreign/domestic origin); bilateral trade balances based on flows of value added embodied in domestic final demand; intermediate imports embodied in exports, participation in GVCs via intermediate imports embodied in exports (backward linkages) and domestic value added in partners' exports (forward linkages); share of industry valued added that meets foreign final demand; origins of value added in final demand, by source country and source industry, including the origin of value added in final consumption (by households and government) and in GFCF (investment by businesses) and inter-regional and intra-regional relationships (OECD, 2015).

3 There is also the World Input-Output Database (WIOD) that covers $27 \mathrm{EU}$ countries and 13 other major world economies and comprises 35 industries (corresponding to a broad NACE classification). This database is created by the financial support through the FP7 project (Amador, Cappariello and Stehrer, 2015). 
2. Foreign value added embodied in gross exports (FVA): refers to the value added of foreign goods and services that are used as intermediates to produce goods and services for export. FVA is usually analyzed by the country of origin.

The disaggregation of data can go further as Koopman et.al (2010) show.

One indicator of GVC is the GVC participation index that calculates the extent to which a country is involved in a vertically-fragmented production process (in relative and absolute terms). This ratio differentiates between the participation of foreign inputs in exports (backward participation) and the use of domestic intermediates in third country exports (forward participation):

GVC participation $=$ DVA $/$ EXP + FVA/EXP,

where DVA is domestic value added (intermediate export) in foreign export, EXP is gross export, FVA is foreign value added (intermediate import) in domestic exports.

Another measure of GVC participation in GVC position is what Koopman et. al (2010) suggest to be measured in the following way:

GVC position $=\log (1+$ DVA/EXP $)-\log (1+$ FVA/EXP $)$.

The GVC position index indicates if a country specializes in the first or the last steps of production. If a country is upstream in the production network (first stages of production), it is likely that it has a high value of forward participation relative to backward. If a country specializes in the last steps of production (downstream), it is likely that it imports a lot of intermediate goods from abroad and therefore it has high backward participation. The GVC position index is constructed in such a way that countries with high forward relative to backward participation record a positive value. These countries lie relatively more upstream in the supply chain (Koopman, et al., 2010).

This research aims to analyze the importance of GVC trade in the EU NMS. 


\subsection{Results and Discussion}

\subsubsection{GVC participation index of EU NMS}

The value of foreign VA in gross export varies from 20 percent (in Croatia) to 48.68 percent (in Hungary) in 2011, while the average for EU-28 amounts up to 28.17 percent. If we look at the trend in the period 1995-2011, there appear to be mixed findings - the foreign VA increased in some countries (the Czech Republic, Hungary, Poland, Slovakia, Slovenia, Bulgaria, Latvia, Romania, Cyprus), while its share decreased in Estonia, Lithuania, Malta, or remained at the same level for over 20 years, as is the case with Croatia. In the EU, foreign VA increased from 19 to 28 percent of gross export. In seven countries, foreign VA exceeds the level of EU-28. The NMS differ significantly in shares of foreign inputs that depend on the export structure, openness of the economy, inflows of foreign capital etc.

Figure 1: Foreign VA in Gross Export in EUNMS

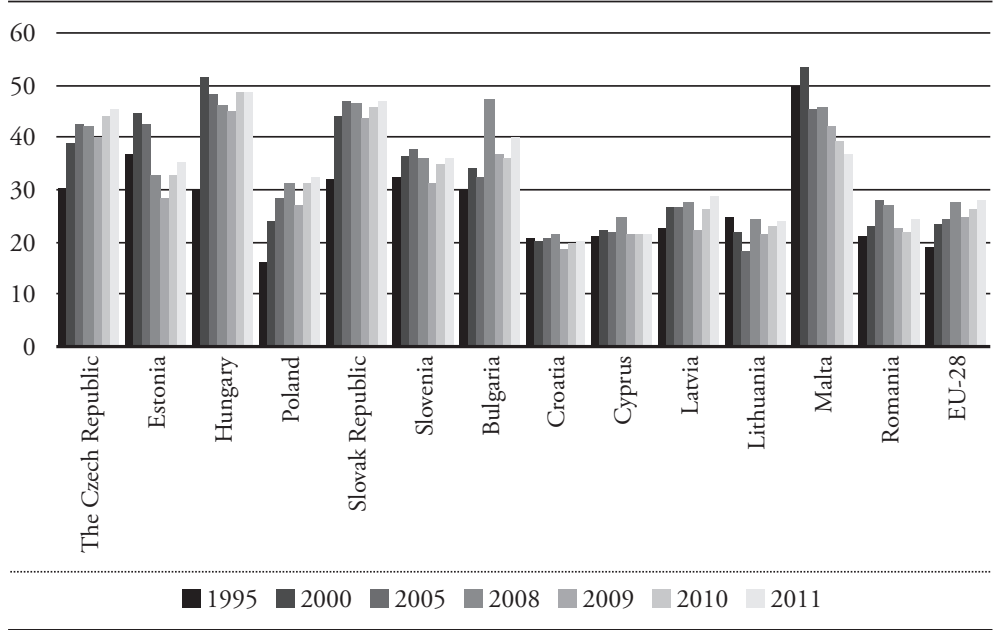

Source: OECD, 2015.

We also want to find out the contribution of the EU common market to the trade of VA since the data indicate that the highest amount of foreign direct investment 
(FDI) inflows in these countries come from EU member states and also that the NMS export is highly oriented toward the EU-28 market (Eurostat, 2016). So this analysis will be performed by analyzing the VA share of EU member states in gross export of EU NMS (1); and by analyzing the origin of VA in final demand in EU NMS (2).

If we look at the detailed data (Table 3 in the Appendix), we can compare the importance of VA from EU member states in gross export of exporting countries. The VA coming from the EU member states represents between 9.19 percent of gross export in Croatia to 27.65 percent in Hungary. The most important source countries are Germany and Italy. The share of Germany VA in gross export varies between 1.38 percent in Cyprus to 9.76 percent in Hungary, while Italy's share goes from 0.87 percent in Lithuania to 4.26 percent of gross export in Slovenia. Furthermore, the importance of source countries can be partially explained by the gravitation model-the smaller the distance between the countries the more trade there is, i.e. Hungary with Austria; the Czech Republic with Poland; the Czech Republic with Poland, France and Austria; Estonia with Finland; Sweden with Latvia etc.

Figure 2: Domestic VA in Gross Export in EUNMS

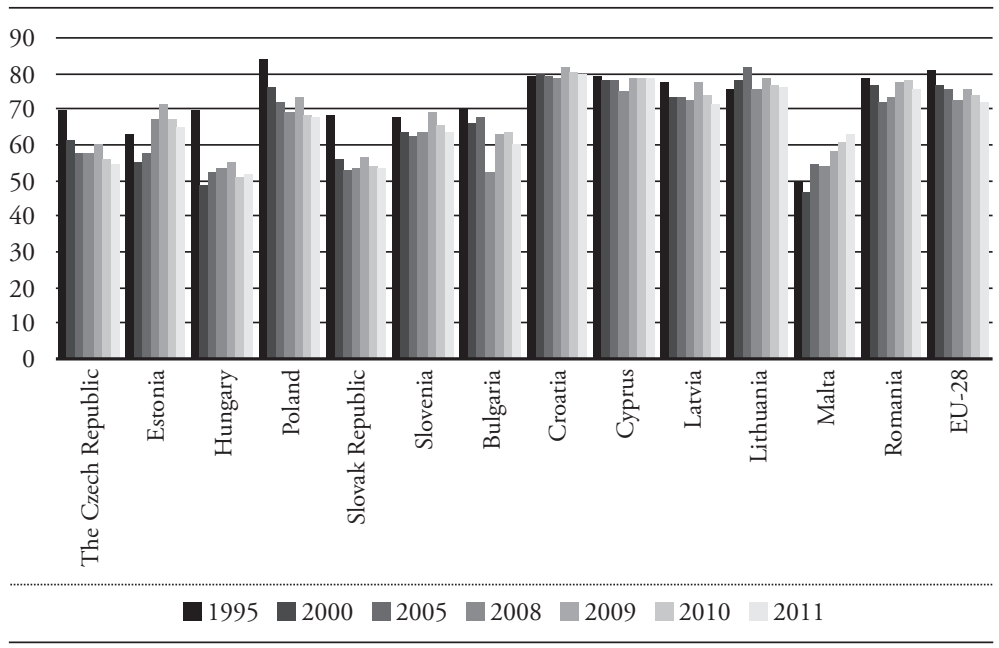

Source: OECD, 2015. 
The shares of domestic VA in total export vary between 51 percent in Hungary and 79 percent in Croatia, in 2011. In most countries, domestic VA shares decreased over the period 1995-2011. At the EU level, the share of domestic VA was 71.8 percent in 2011.

Table 4 in the Appendix shows the interconnection among EU member states regarding the origin of VA in final demand for 2011. The VA coming from the EU (if we are not counting the domestic share) goes from 15.09 percent in Croatia to 26.04 percent of final demand in Malta. The EU shares in the majority of EU NMS are higher than 20 percent. The highest share of domestic VA in final demand can be found in Croatia at 70.88 percent, while the lowest level can be found in Bulgaria and Slovakia at 58 percent. The total EU share (together with domestic) varies from 79.76 percent in Slovakia to 86.78 percent in Latvia. Here, we can also find a huge concentration of VA from Germany and Italy in final demand, but France, Poland, and the UK also have significant shares. Historical relationships are also evident in the cases of the Czech Republic-Slovakia, and Latvia-Lithuania.

The GVC participation index has been calculated. EU NMS have increased participation in GVC in 2011 in comparison with 1995 (Figure 3). The highest increase was registered in Poland-increasing from an index of 36 to 56, and in Hungary-increasing from 43 to 65. Only Malta and Croatia have registered a decrease in GVC participation for 6 percent and 3 percent. The highest GVC participation index belongs to Slovakia (followed by Hungary and the Czech Republic) and the lowest to Croatia. The EU-28 has an index of 47 and in the EU NMS, the average index is 54. Regarding the structure of GVCs in all countries, the backward participation dominates, i.e. they are highly dependent on the import of intermediates for the production and export of final products. 
Figure 3: GVC Participation Index for EU NMS in 1995 and 2011

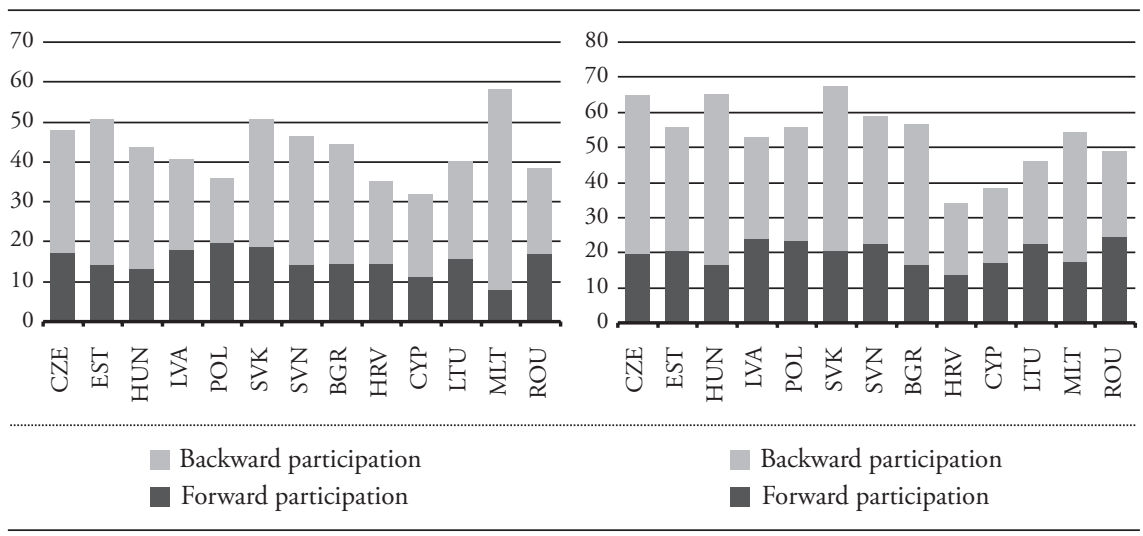

Source: OECD, 2015.

Figure 4: GVC Position of EU NMS in 2000 and 2011

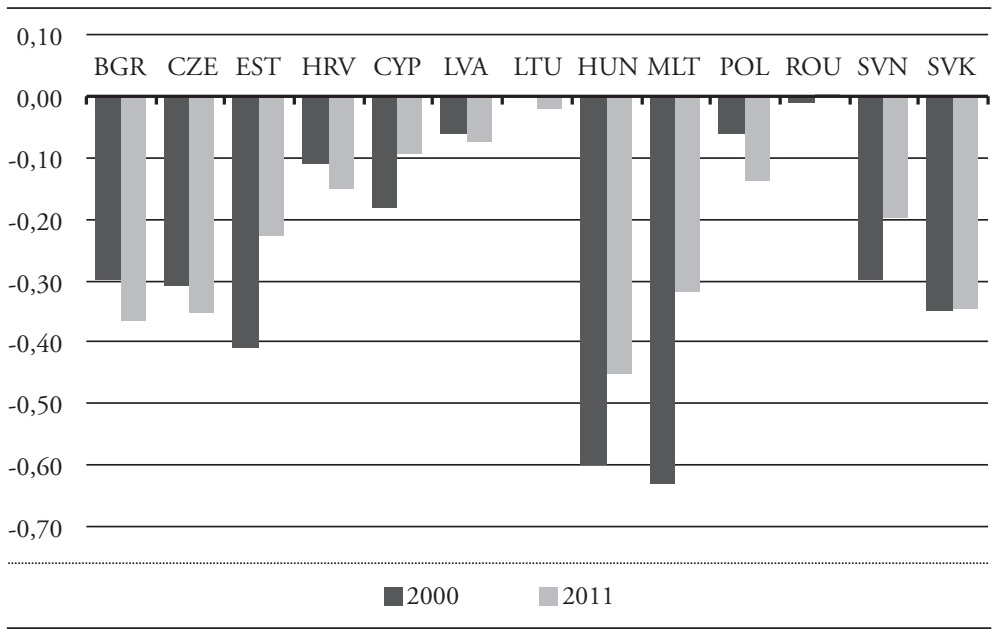

Source: OECD, 2015.

Figure 4 indicates that all of the EU NMS lie relatively more downstream in a supply chain - they have high values of backward participation (they depend on the import of intermediates from abroad). 
Figure 5: Final Product Shares in Gross Export

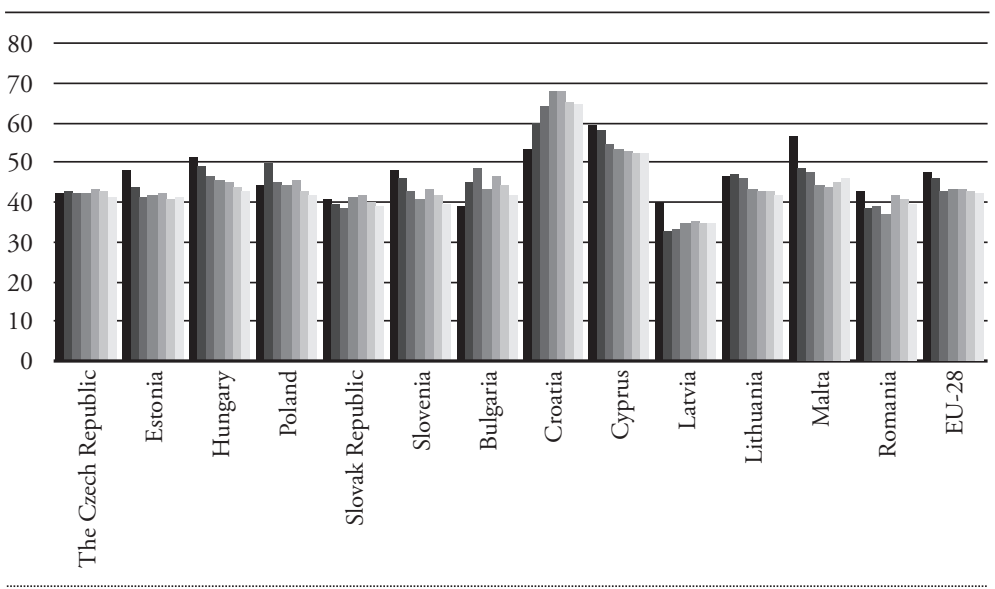

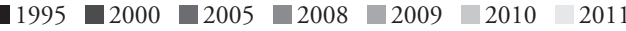

Source: OECD, 2015.

Figure 6: Intermediate Products Share in Gross Export

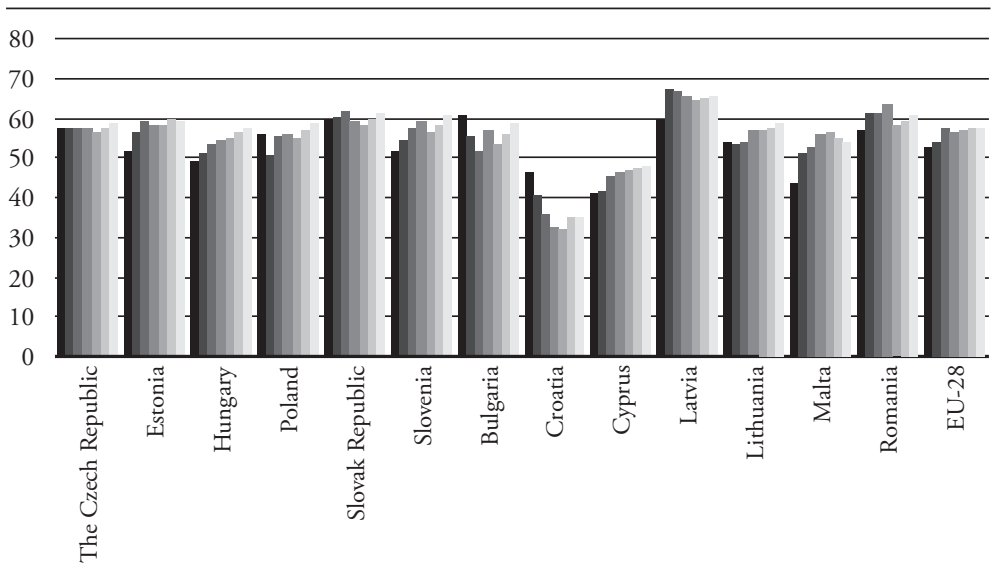


Figures 5 and 6 show the shares of final and intermediate products in total export. Final product shares range from 38 percent in Slovakia to 64.7 percent in Croatia, in 2011. In the majority of countries, shares were declining from 1995 to 2011. EU-28 shares declined from 47 to 42 percent of total export. The shares of intermediate products go in the opposite direction: they have an increasing trend and in 2011 the highest value was registered in Slovakia. Croatia has the lowest share of intermediate products in its export and also the lowest value of foreign VA, which means that it is at least included in the global value chain or trade in VA. It is connected with the sector structure of export.

Regarding the purpose of imported intermediate products, the countries face different situations: on the one hand, there are countries such as Hungary, Slovakia, and the Czech Republic, which export more than 60 percent (Hungary even 70 percent) of imported intermediates, while the worst situation can be found in Romania and Croatia, which export only slightly more than 30 percent of imported intermediates.

As the EU NMS are faced with the declining importance of industry in their economies (in GDP and employment), Havlik (2014) investigated the structural reforms in these countries in the period 1995-2011 with the assumption that the shifts toward more productive branches should boost aggregate productivity. These countries have experienced important changes during their transition to market economies with the huge decrease of industrial production-only the Czech Republic and Romania have the industry share in GDP more than 20 percent. Industry shares in GDP in all other EU NMS are below 20 percent.

\subsubsection{FDI inward stocks and GVC participation}

As is already known, FDI inflows play a very important role in the production fragmentation, widening the MNC activities and, as is supposed, enable a higher level of GVC participation in EU NMS from Central and East Europe (CEE). Here, the relationship between FDI inward stocks and GVC participation in the industry of CEE countries will be investigated. CEE region became 
an attractive FDI region for EU-15 and rest of the world during the process of transition (starting at the beginning of 1990s) with the additional pushing factor membership in the EU (2004; 2007 and 2013). They have received a large amount of foreign capital where FDI inward stock amounts from EUR 7.4 billion in Latvia to EUR 156 billion in Poland, or in relative terms: from EUR 2597 per capita in Romania to EUR 9034 per capita in Estonia, and EUR 8611 per capita in the Czech Republic (in 2012, according to the Eurostat database). A large part of investment was oriented toward the service sector: banking, insurance, retail trade with a focus on service on the domestic markets and with limited impact on export. One part of the investment also went into the manufacturing sector, where it represents just 10 percent of total inward FDI stock on the EU level, but in the EU new CEE members, manufacturing attracted higher shares-from 16 percent of total FDI inward stock in Latvia to 36 percent of total FDI inward stock in the Czech Republic and Poland. The most attractive manufacturing sectors were: machinery and equipment; transport equipment; wood processing; rubber and plastic production; food production; and computers, electronics and optical products production.

Figure 7: FDI Inward Stock in Manufacturing, \% of the Total FDI Inward Stock, in 2011

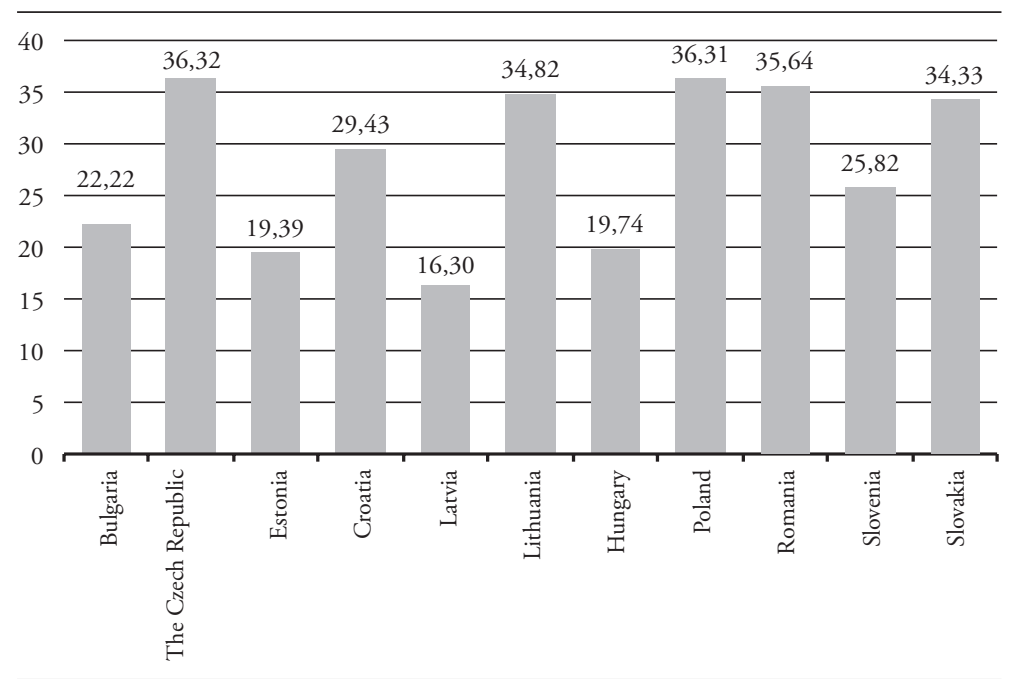

Source: Eurostat (2016) and author's calculations. 
Table 1 shows the correlation coefficient between FDI inward stock in manufacturing sectors and GVC participation indexes in the corresponding sectors.

Table 1: Correlation between FDI Inward Stock in Manufacturing Sectors in CEE Countries and GVC Participation Index, in 2011

\begin{tabular}{l|c}
\hline Sectors & Correlation coefficient \\
\hline Manufacturing & 0.21 \\
\hline Manufacture of food products; beverages and tobacco products & -0.31 \\
\hline $\begin{array}{l}\text { Manufacture of textiles, wearing apparel, wood and paper products; } \\
\text { printing and reproduction }\end{array}$ & -0.10 \\
\hline Manufacture of wood, paper, printing and reproduction & -0.10 \\
\hline $\begin{array}{l}\text { Manufacture of chemicals and chemical products } \\
\text { Manufacture of metal and machinery products, except electrical } \\
\text { equipment }\end{array}$ & 0.006 \\
\hline $\begin{array}{l}\text { Manufacture of basic metals and fabricated metal products, except } \\
\text { machinery and equipment }\end{array}$ & 0.20 \\
\hline $\begin{array}{l}\text { Manufacture of computers, electronics and optical products } \\
\text { Manufacture of machinery and equipment }\end{array}$ & 0.10 \\
\hline $\begin{array}{l}\text { Manufacture of motor vehicles, trailers, semi-trailers and of other } \\
\text { transport equipment }\end{array}$ & 0.60 \\
\hline
\end{tabular}

Source: OECD, 2015.

By calculating the correlation coefficients, a weak correlation between these two variables has been found. Manufacturing has the coefficient of 0.20 . In some sectors the coefficients were negative (food production; textile manufacture, wood manufacture), while in others the coefficients are positive but below 0.5 . Only in one sector (computers, electronics and optical products manufacture) a coefficient of 0.6 has been found indicating a medium positive interrelation between FDI inward stocks and GVC participation index. These results mainly support Ravenhill's (2014) thesis that the participation in GVC is not just the result of FDI inflows, although they played an inevitable role in the transition and post-transition period in the CEE region. He warns that significant numbers of GVCs are associated with little or no FDI. "This characteristics is particularly evident in what are often referred to as 'buyer-driven' chains that dominate 
the textile and apparel industry, for instance. Here the principal contribution of the lead firms to their suppliers is to provide the specifications to which goods are produced (and of course the marketing channels through which the final products are sold). Even in more technologically-intensive sectors such as automobiles, the principal contribution of the lead firms in a value chain may be to provide blueprints and often technical assistance to their suppliers, sometimes seconding their engineers to work at their suppliers' manufacturing plants. No equity relationship is involved" (Ravenhill, 2014: 5).

\subsubsection{GVC participation on the industry level}

The next step should reveal if the imports of intermediates influence the export of final products in a particular industry. These increases have been calculated:

- Import of intermediate products in every sector and country;

- Export of final products in every sector and country, in 2011 compared to 2000 .

Subsequently, the correlation coefficient between these two variables (rise in the export of final products and the rise in import of intermediaries) is estimated on the industry sector level.

From Table 2 we can see the differences in the dependence between the import of intermediates and the export of final products-the highest level of correlation (very strong) was found in the sectors: computers, electronics and optical products manufacture and the manufacture of wood, paper, printing and reproduction, while the lowest level of correlation was found in the sector of food production. The results are in line with the findings of Leitner and Stehrer (2014), i.e. a high degree of vertical specialization can be found in the electrical and optical equipment industry, which is economy's largest-and apparently highly vertically specialized-manufacturing industry. Increases in their degrees 
of vertical specialization are also the result of their rather rapid integration into the European economy (as is confirmed by the data from the Appendix).

Table 2: Correlation between the Import of Intermediate Products and the Export of Final Goods in CEE Countries

\begin{tabular}{l|c}
\hline Sectors & Correlation coefficient \\
\hline Manufacturing & 0.95 \\
Manufacture of food products; beverages and tobacco products & 0.07 \\
$\begin{array}{l}\text { Manufacture of textiles, wearing apparel, wood and paper products; } \\
\text { printing and reproduction }\end{array}$ & 0.74 \\
Manufacture of wood, paper, printing and reproduction & 0.83 \\
Manufacture of chemicals and chemical products & 0.13 \\
Manufacture of basic metals and fabricated metal products, except \\
machinery and equipment
\end{tabular}

Source: OECD, 2015.

\section{Conclusion}

Trade in value added (TiVA) has become the latest topic in international trade research with regard to the fact that the official statistical (export) data are overestimated due to the multiple registering of the same value (or part of the value) of export (in the case of export of intermediate products). So, as much as the intermediate products are represented in trade, the gross export is overestimated. The methodology of measuring TiVA is still developing but there are a few databases that calculate the international input-output tables that are the necessary foundation for finding the interconnection among the countries.

In this paper, the focus is placed on the analysis of TiVA in EU new member states (NMS). On the basis of foreign and domestic value added share in gross export, it has been established that the most integrated country is Hungary and the least integrated Croatia. Croatia also has the lowest level of intermediate goods in export, which also indicates its low level of participation in GVC. 
By analyzing the detailed structure of EU interconnections, it has been established that the value added (VA) coming from EU member states represents between 9.19 percent of gross export in Croatia and 27.65 percent in Hungary. The most important source countries are Germany and Italy and there is also evidence of geographical and historical relations between the countries (LatviaLithuania; the Czech Republic-Slovakia). The analysis of VA origin in final demand indicates that the VA coming from the EU (if we do not count the domestic share) goes from 15.09 percent in Croatia to 26.04 percent of final demand in Malta. The EU shares in the majority of EU NMS are higher than 20 percent. The highest share of domestic VA in final demand is in Croatia and it is set at 70.88 percent, while the lowest level, set at 58 percent, is registered in Bulgaria and Slovakia. The total EU share (together with domestic) varies from 79.76 percent in Slovakia to 86.78 percent in Latvia.

A regional GVC has been found in Europe because a huge part of VA, in gross export as well as in final demand (Europe as a hub), comes from EU member states with the domination of Germany and Italy. Amador, Cappariello and Stehrer (2015) present similar findings in their analysis of the GVC in the eurozone-they also identify Germany as the main country playing a pivotal role in the production linkages.

The EU NMS have a domination of backward linkages, i.e. they are very dependent on the intermediates' imports from abroad, which put them in the downstream part of the production chain. A special analysis of GVC participation at the industry sectors levels has also been made in order to determine the importance of intermediates' import for the export growth (competitiveness) of final products. The research results indicate differences in the dependence between the import of intermediates and export of final products - the highest level of correlation (very strong) was found in the sectors: computers, electronics and optical products manufacture and in the manufacture of wood, paper, printing and reproduction, while the lowest level of correlation was detected in the sector of food production. It is in line with the research presented by Olczyk 
and Kordalska (2017), who found a decrease in domestic value added in hightech industries.

Even the low participation in GVC may not be a negative feature by itself, in the case of small EU member countries-it can be a sign of insufficient integration into the single EU market and unsatisfactory exploitation of its potential (as is the case of Croatia). Also, it can be an indicator of an unfavorable industrial structure. Croatia became an EU member only in 2013 and maybe this is also one of the reasons for its worst position in GVC participation among EU NMS. These findings can be useful for policy makers. By attracting and focusing the investments onto high-tech sectors, the country can increase its participation in GVCs. Additionally, it can influence higher employment rates and decrease the emigration trends.

These are the main indicators of TiVA in EU NMS, and with this research an opportunity for further analysis has been enabled. Of special importance could be the analysis of revealed comparative advantage (RCA) for EU NMS based on the sectoral level data (according to Koopman, Wang and Wei, 2014), but also the establishment of determinants of such calculated RCA (connection with the quality of work [new 'new' trade theory]: productivity; highly-skilled employees; technology development; innovativeness). Additionally, one interesting area of research can be the study of interrelation or dependence of industrial GVC participation on service (domestic and foreign) value added. 


\section{Appendix}

Table 3: Origin of VA in Gross Export in EUNMS

\begin{tabular}{l|l|l|l|l|l|l|l|l|l|l|l|l|l}
\hline CZE EST & HUN POL SVK & SVN & BGR HRV & CYP LVA & LTU MLT ROU \\
\hline
\end{tabular}

\begin{tabular}{|c|c|c|c|c|c|c|c|c|c|c|c|c|c|}
\hline AUT & 1.19 & 0.30 & 1.85 & 0.57 & 0.87 & 2.24 & 0.79 & 0.67 & 0.17 & 0.41 & 0.18 & 0.67 & 0.70 \\
\hline BEL & 0.61 & 0.54 & 0.66 & 0.51 & 0.48 & 0.45 & 0.39 & 0.21 & 0.37 & 0.41 & 0.28 & 0.62 & 0.29 \\
\hline CZE & & 0.33 & 1.06 & 0.90 & 2.92 & 0.66 & 0.41 & 0.23 & 0.06 & 0.34 & 0.22 & 0.08 & 0.40 \\
\hline DNK & 0.30 & 0.53 & 0.31 & 0.34 & 0.17 & 0.17 & 0.18 & 0.14 & 0.10 & 0.49 & 0.34 & 1.77 & 0.15 \\
\hline EST & 0.02 & & 0.01 & 0.02 & 0.01 & 0.01 & 0.01 & 0.00 & 0.04 & 1.41 & 0.64 & 0.02 & 0.01 \\
\hline FIN & 0.19 & 3.52 & 0.23 & 0.32 & 0.13 & 0.13 & 0.09 & 0.06 & 0.05 & 0.97 & 0.61 & 0.07 & 0.08 \\
\hline FRA & 1.73 & 0.96 & 1.90 & 1.56 & 1.82 & 1.52 & 0.99 & 0.52 & 0.80 & 0.85 & 0.48 & 1.32 & 1.16 \\
\hline DEU & 9.50 & 3.53 & 9.76 & 6.00 & 6.43 & 5.77 & 3.01 & 2.17 & 1.38 & 3.06 & 2.05 & 4.55 & 3.29 \\
\hline GRC & 0.12 & 0.13 & 0.09 & 0.11 & 0.09 & 0.16 & 1.42 & 0.06 & 3.03 & 0.13 & 0.11 & 0.17 & 0.28 \\
\hline HUN & 0.62 & 0.24 & $\ldots$ & 0.35 & 0.81 & 0.50 & 0.53 & 0.28 & 0.05 & 0.18 & 0.10 & 0.05 & 0.84 \\
\hline IRL & 0.32 & 0.25 & 0.49 & 0.20 & 0.16 & 0.33 & 0.28 & 0.11 & 0.15 & 0.25 & 0.11 & 0.46 & 0.13 \\
\hline ITA & 2.00 & 0.90 & 2.21 & 1.80 & 1.67 & 4.26 & 2.09 & 2.22 & 1.18 & 1.10 & 0.87 & 3.82 & 2.33 \\
\hline LUX & 0.10 & 0.10 & 0.11 & 0.08 & 0.07 & 0.11 & 0.06 & 0.05 & 0.30 & 0.10 & 0.05 & 0.39 & 0.05 \\
\hline NLD & 0.63 & 0.72 & 0.99 & 0.61 & 0.38 & 0.37 & 0.36 & 0.24 & 0.44 & 0.48 & 0.56 & 0.47 & 0.36 \\
\hline POL & 2.66 & 1.49 & 1.83 & $\cdots$ & 1.62 & 0.71 & 0.58 & 0.29 & 0.18 & 1.91 & 1.73 & 0.21 & 0.89 \\
\hline PRT & 0.15 & 0.06 & 0.11 & 0.10 & 0.10 & 0.08 & 0.09 & 0.03 & 0.05 & 0.04 & 0.04 & 0.07 & 0.08 \\
\hline SVK & 1.48 & 0.10 & 1.11 & 0.44 & & 0.38 & 0.19 & 0.10 & 0.03 & 0.13 & 0.12 & 0.02 & 0.26 \\
\hline SVN & 0.17 & 0.05 & 0.29 & 0.10 & 0.15 & $\ldots$ & 0.13 & 0.63 & 0.02 & 0.06 & 0.03 & 0.02 & 0.09 \\
\hline ESP & 1.01 & 0.49 & 0.86 & 0.76 & 0.69 & 0.72 & 1.77 & 0.28 & 0.53 & 0.64 & 0.50 & 1.35 & 0.57 \\
\hline SWE & 0.58 & 2.77 & 0.79 & 0.81 & 0.44 & 0.40 & 0.34 & 0.22 & 0.19 & 1.20 & 0.85 & 1.27 & 0.20 \\
\hline GBR & 1.35 & 1.36 & 1.63 & 1.26 & 1.10 & 1.02 & 0.83 & 0.46 & 2.66 & 0.79 & 0.71 & 6.43 & 0.81 \\
\hline BGR & 0.09 & 0.03 & 0.10 & 0.07 & 0.07 & 0.12 & $\ldots$ & 0.08 & 0.08 & 0.04 & 0.03 & 0.16 & 0.39 \\
\hline HRV & 0.05 & 0.01 & 0.10 & 0.02 & 0.05 & 0.87 & 0.02 & & 0.02 & 0.01 & 0.01 & 0.02 & 0.02 \\
\hline CYP & 0.02 & 0.29 & 0.03 & 0.01 & 0.01 & 0.01 & 0.16 & 0.00 & $\ldots$ & 0.13 & 0.01 & 1.04 & 0.07 \\
\hline LVA & 0.03 & 2.03 & 0.02 & 0.04 & 0.02 & 0.01 & 0.02 & 0.01 & 0.10 & $\ldots$ & 1.37 & 0.03 & 0.01 \\
\hline LTU & 0.04 & 0.95 & 0.03 & 0.14 & 0.03 & 0.02 & 0.04 & 0.01 & 0.07 & 2.92 & $\ldots$ & 0.01 & 0.02 \\
\hline MLT & 0.00 & 0.01 & 0.00 & 0.01 & 0.00 & 0.00 & 0.00 & 0.00 & 0.01 & 0.00 & 0.01 & $\ldots$ & 0.01 \\
\hline ROU & 0.27 & 0.07 & 1.07 & 0.18 & 0.29 & 0.25 & 1.57 & 0.10 & 0.28 & 0.06 & 0.04 & 0.06 & \\
\hline $\begin{array}{l}\text { FVA from } \\
\text { the EU }\end{array}$ & 25.21 & 21.77 & 27.65 & 17.31 & 20.57 & 21.26 & 16.35 & 9.19 & 12.33 & 18.11 & 12.03 & 25.15 & 13.45 \\
\hline
\end{tabular}

Note: The source countries are in rows and exporting countries in columns.

Source: OECD, 2015. 
Table 4: Origin of VA in Final Demand in EU NMS

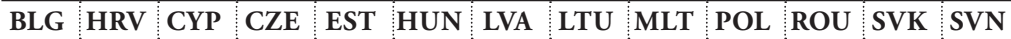

\begin{tabular}{|c|c|c|c|c|c|c|c|c|c|c|c|c|c|}
\hline AUT & 1.31 & 1.09 & 0.27 & 1.21 & 0.34 & 2.09 & 0.55 & 0.32 & 0.58 & 0.58 & 0.95 & 1.09 & 2.20 \\
\hline BEL & 0.51 & 0.28 & 0.51 & 0.56 & 0.46 & 0.57 & 0.52 & 0.40 & 0.56 & 0.46 & 0.36 & 0.44 & 0.40 \\
\hline CZE & 0.71 & 0.37 & 0.13 & 61.24 & 0.36 & 0.96 & 0.45 & 0.38 & 0.09 & 0.83 & 0.51 & 3.56 & 0.65 \\
\hline DNK & 0.25 & 0.21 & 0.18 & 0.35 & 0.55 & 0.28 & 0.68 & 0.56 & 1.36 & 0.38 & 0.20 & 0.18 & 0.17 \\
\hline EST & 0.01 & 0.01 & 0.05 & 0.01 & 58.65 & 0.01 & 1.73 & 1.04 & 0.02 & 0.02 & 0.01 & 0.01 & 0.01 \\
\hline FIN & 0.11 & 0.12 & 0.10 & 0.14 & 3.90 & 0.16 & 1.38 & 1.21 & 0.07 & 0.26 & 0.09 & 0.11 & 0.10 \\
\hline FRA & 1.46 & 1.05 & 1.65 & 1.40 & 1.32 & 1.56 & 1.50 & 1.10 & 1.69 & 1.49 & 1.77 & 1.47 & 1.57 \\
\hline DEU & 4.95 & 3.74 & 2.67 & 8.15 & 5.12 & 7.99 & 4.55 & 4.01 & 3.99 & 5.62 & 4.13 & 5.10 & 5.84 \\
\hline GRC & 2.19 & 0.09 & 5.90 & 0.16 & 0.12 & 0.09 & 0.12 & 0.18 & 0.22 & 0.13 & 0.37 & 0.09 & 0.20 \\
\hline HUN & 0.90 & 0.45 & 0.10 & 0.61 & 0.23 & 59.25 & 0.26 & 0.19 & 0.08 & 0.35 & 1.25 & 1.09 & 0.65 \\
\hline IRL & 0.33 & 0.16 & 0.22 & 0.33 & 0.28 & 0.39 & 0.31 & 0.22 & 0.38 & 0.24 & 0.16 & 0.19 & 0.29 \\
\hline ITA & 3.22 & 3.31 & 2.18 & 1.96 & 1.40 & 1.98 & 1.89 & 1.72 & 5.45 & 1.85 & 3.02 & 1.74 & 4.65 \\
\hline LUX & 0.07 & 0.08 & 0.30 & 0.11 & 0.09 & 0.13 & 0.13 & 0.08 & 0.35 & 0.09 & 0.05 & 0.10 & 0.13 \\
\hline NLD & 0.56 & 0.40 & 0.67 & 0.67 & 0.72 & 0.99 & 0.67 & 0.95 & 0.56 & 0.68 & 0.51 & 0.45 & 0.43 \\
\hline POL & 1.04 & 0.49 & 0.28 & 2.48 & 1.79 & 1.70 & 2.75 & 3.28 & 0.27 & 68.81 & 1.01 & 2.12 & 0.78 \\
\hline PRT & 0.10 & 0.05 & 0.10 & 0.13 & 0.08 & 0.10 & 0.07 & 0.06 & 0.09 & 0.10 & 0.10 & 0.08 & 0.08 \\
\hline SVK & 0.32 & 0.16 & 0.06 & 1.55 & 0.11 & 1.10 & 0.19 & 0.18 & 0.03 & 0.43 & 0.29 & 58.62 & 0.35 \\
\hline SVN & 0.17 & 1.06 & 0.03 & 0.13 & 0.06 & 0.38 & 0.08 & 0.05 & 0.03 & 0.07 & 0.12 & 0.15 & 60.81 \\
\hline ESP & 1.42 & 0.54 & 1.23 & 1.00 & 0.64 & 0.85 & 0.93 & 0.77 & 1.62 & 0.88 & 0.84 & 0.71 & 0.87 \\
\hline SWE & 0.46 & 0.31 & 0.28 & 0.48 & 2.65 & 0.57 & 1.57 & 1.41 & 1.10 & 0.71 & 0.24 & 0.37 & 0.33 \\
\hline GBR & 1.33 & 0.79 & 4.98 & 1.20 & 1.78 & 1.35 & 1.39 & 1.26 & 6.16 & 1.36 & 1.21 & 1.35 & 1.12 \\
\hline BLG & 58.00 & 0.11 & 0.15 & 0.10 & 0.04 & 0.11 & 0.07 & 0.07 & 0.17 & 0.09 & 0.56 & 0.06 & 0.17 \\
\hline HRV & 0.07 & 70.88 & 0.03 & 0.15 & 0.02 & 0.29 & 0.02 & 0.01 & 0.04 & 0.08 & 0.04 & 0.38 & 1.96 \\
\hline CYP & 0.22 & 0.01 & 61.86 & 0.03 & 0.36 & 0.05 & 0.15 & 0.02 & 0.98 & 0.02 & 0.09 & 0.01 & 0.01 \\
\hline LVA & 0.02 & 0.01 & 0.09 & 0.02 & 2.13 & 0.02 & 61.24 & 2.13 & 0.04 & 0.04 & 0.02 & 0.02 & 0.01 \\
\hline LTU & 0.05 & 0.02 & 0.07 & 0.04 & 1.09 & 0.03 & 3.48 & 64.55 & 0.01 & 0.18 & 0.02 & 0.03 & 0.02 \\
\hline MLT & 0.01 & 0.00 & 0.35 & 0.00 & 0.01 & 0.00 & 0.01 & 0.01 & 59.44 & 0.02 & 0.01 & 0.00 & 0.00 \\
\hline ROU & 2.19 & 0.18 & 2.13 & 0.22 & 0.09 & 0.92 & 0.09 & 0.08 & 0.08 & 0.16 & 70.39 & 0.24 & 0.26 \\
\hline $\mathrm{EU}$ & 82.00 & 85.97 & 86.57 & 84.43 & 84.39 & 83.92 & 86.78 & 86.24 & 85.49 & 85.93 & 88.32 & 79.76 & 84.08 \\
\hline EU-domestic & 24.00 & 15.09 & 24.71 & 23.19 & 25.74 & 24.67 & 25.54 & 21.69 & 26.04 & 17.12 & 17.93 & 21.14 & 23.27 \\
\hline
\end{tabular}

Source: OECD, 2015. 


\section{Literature}

Amador, João, Rita Cappariello and Robert Stehrer, 2015, "Global Value Chains: A View from the Euro Area”, ECB Working Paper, No. 1761, March, Frankfurt am Main: European Central Bank (ECB).

Daudin, Guillaume, Christine Rifflart and Danielle Schweisguth, 2011, "Who Produces for Whom in the World Economy?", Canadian Journal of Economics, 44(4), pp. 1403-1437. https://doi.org/10.1111/j.1540-5982.2011.01679.x

De Backer, Koen and Sébastien Miroudot, 2013, "Mapping Global Value Chains", OECD Trade Policy Papers, No. 159, December, Paris: OECD Publishing. http://dx.doi.org/10.1787/5k3vltrgnbr4-en

Escaith, Hubert, 2015, "Closing the Gaps between Trade Theories, Trade Policies and Global Production Statistics: A Practitioner's Perspective”, paper presented at the conference "Conference of European Statisticians Group of Experts on National Accounts" organized by UNECE, Geneva, July 7-9. http://dx.doi. org/10.2139/ssrn.2629090

Eurostat, 2016, Eurostat Database, http://epp.eurostat.ec.europa.eu/ (accessed July 2, 2016).

Ferrarini, Benno and Pasquale Scaramozzino, 2011, "Indicators and Patterns of Specialization in International Trade", NCCR Working Paper, No. 10, March, Bern: Swiss National Centre of Competence in Research.

Friedman, Thomas L., 2005, The World is Flat: A Brief History of the $21^{1 t}$ Century. New York, NY: Farrar, Straus and Giroux.

Fronczek, Malgorzata, 2016, "Position of EU-15 in World Export in Comparison to Selected Countries in a View of Measuring Trade in Value Added" in Tomas Kliestik, ed., Proceedings of the $16^{\text {th }}$ International Scientific Conference on Globalization and its Socio-Economic Consequences, pp. 458-467, Zilina: University of Zilina, http://ke.uniza.sk/sites/default/files/content_files/part_i_ final_2.pdf (accessed October 18, 2017). 
Gereffi, Gary and Karina Fernandez-Stark, 2011, Global Value Chain Analysis: A Primer, Durham, NC: Duke University, Center on Globalization, Governance \& Competitiveness (CGGC).

Havlik, Peter, 2014, "Patterns of Structural Change in the New EU Member States", wiiw Research Report, No. 394, April, Vienna: The Vienna Institute for International Economic Studies (wiiw).

Hummels, David, Jun Ishii and Kei-Mu Yi, 2001, "The Nature and Growth of Vertical Specialization in World Trade", Journal of International Economics, 54(1), pp. 75-96. https://doi.org/10.1016/S0022-1996(00)00093-3

Javorsek, Marko and Ignacio Camacho, 2015, "Trade in Value Added: Concepts, Estimation and Analysis", ARTNeT Working Paper Series, No. 150, May, Bangkok: United Nations Economic and Social Commission for Asia and the Pacific (ESCAP).

Jiang, Xiao and William Milberg, 2013, "Capturing the Jobs from Globalization: Trade and Employment in Global Value Chains", The New School for Social Science Research Working Paper, No. 30, April, New York, NY: The New School for Social Science Research (NSSSR).

Johnson, Robert C. and Guillermo Noguera, 2012, "Accounting for Intermediates: Production Sharing and Trade in Value Added", Journal of International Economics, 86(2). pp. 224-236. https://doi.org/10.1016/j.jinteco.2011.10.003

Koopman Robert, William Powers, Zhi Wang and Snag-Jin Wei, 2010, "Give Credit Where Credit is Due: Tracing Value Added in Global Production Chains", NBER Working Paper, No. 16426, September 2010, revised September 2011, Cambridge, MA: National Bureau of Economic Research (NBER), http://www. nber.org/papers/w16426 (accessed January 15, 2016).

Koopman, Robert, Zhi Wang and Snag-Jin Wei, 2014, “Tracing Value-Added and Double Counting in Gross Exports", American Economic Review, 104(2), pp. 459-494. https://doi.org/10.1257/aer.104.2.459 
Krugman, Paul R., 1979, "Increasing Returns, Monopolistic Competition, and International Trade", Journal of International Economics, 9(4). pp. 469-479. https://doi.org/10.1016/0022-1996(79)90017-5

Kwon, Taehyun and Jai-Won Ryou, 2015, "Global Value Chains of East Asia: Trade in Value Added and Vertical Specialization", Asian Economic Journal, 29(2), pp. 121-143. https://doi.org/10.1111/asej.12051

Leitner, Sandra M. and Robert Stehrer, 2014, "Trade Integration, Production Fragmentation and Performance in Europe - Blessing or Curse? A Comparative Analysis of the New Member States and the EU-15", wiiw Research Report, No. 397, November, Vienna: The Vienna Institute for International Economic Studies (wiiw).

Melitz, Marc, 2003, "The Impact of Trade on Intra-Industry Reallocations and Aggregate Industry Productivity", Econometrica, 71(6), pp. 1695-1725. https:// doi.org/10.1111/1468-0262.00467

Nagengast, Arne J. and Robert Stehrer, 2015, “The Great Collapse in Value Added Trade", wiiw Working Paper, No. 112, April, Vienna: The Vienna Institute for International Economic Studies (wiiw).

Olczyk, Magdalena and Aleksandra Kordalska, 2017, "Gross Exports versus Value-Added Exports: Determinants and Policy Implications for Manufacturing Sectors in Selected CEE Countries", Eastern European Economics, 55(1), pp. 91109. https://doi.org/10.1080/00128775.2016.1254564

Porter, Michael E., 1990, The Competitive Advantage of Nations, New York, NY: Free Press.

Ravenhill, John, 2014, "Global Value Chains and Development", Review of International Political Economy, 21(1), pp. 264-274. https://doi.org/10.1080/09 692290.2013 .858366 
Rifflart, Christine and Danielle Schweisguth, 2013, "Report on New Measures of International Trade", e-Frame Deliverable 6.1, March: e-Frame - European Framework for Measuring Progress, http://citeseerx.ist.psu.edu/viewdoc/downlo ad?doi=10.1.1.370.9884\&rep=rep1\&type=pdf (accessed January 15, 2016).

Stehrer, Robert, Neil Foster and Gaaitzen de Vries, 2012, "Value Added and Factors in Trade: A Comprehensive Approach", wiiw Working Paper, No. 80, June, Vienna: The Vienna Institute for International Economic Studies (wiiw).

Stephenson, Sherry M., 2013, "Global Value Chains: The New Reality of International Trade", E15Initiative, Geneva: International Centre for Trade and Sustainable Development (ICTSD) and World Economic Forum, http://e15initiative.org/publications/global-value-chains-the-new-reality-ofinternational-trade/ (accessed January 15, 2016).

The Organisation for Economic Co-operation and Development (OECD), 2013, Interconnected Economies: Benefitting from Global Value Chains, Paris: OECD Publishing.

The Organisation for Economic Co-operation and Development (OECD), 2015, Trade in Value Added (TiVA) - October 2015, http://stats.oecd.org/Index. aspx?DataSetCode=TIVA2015_C1 (accessed February 18, 2016).

The World Trade Organization (WTO), 2010, "Globalization of Industrial Production Chains and Measurement of Trade in Value Added", proceedings of a joint conference by the Senate Finance Commission and the Secretariat of the World Trade Organization (WTO) held in Paris on October 15, 2010, Geneva: The World Trade Organization (WTO), https:/www.wto.org/english/ forums_e/public_forum11_e/globalization_industrial_production.pdf (accessed January 15, 2016).

The World Trade Organization (WTO) and The Institute of Developing Economies - Japan External Trade Organization (IDE-JETRO), 2011, Trade Patterns and Global Value Chains in East Asia: From Trade in Goods to Trade in Tasks, Geneva: The World Trade Organization (WTO), https://www.wto.org/ english/res_e/booksp_e/stat_tradepat_globvalchains_e.pdf (accessed January 15, 2016). 
Timmer, Marcel P., Bart Los, Robert Stehrer and Gaaitzen de Vries, 2013, "Fragmentation, Incomes and Jobs. An Analysis of European Competitiveness", Economic Policy, 28(76), pp. 613-661. https://doi.org/10.1111/1468-0327.12018

United Nations Conference on Trade and Development (UNCTAD), 2013a, Global Value Chains and Development: Investment and Value Added Trade in Global Economy, A Preliminary Analysis, Geneva: United Nations Publications, http://unctad.org/en/publicationslibrary/diae2013d1_en.pdf (accessed January 15, 2016).

United Nations Conference on Trade and Development (UNCTAD), 2013b, World Investment Report 2013, Global Value Chains: Investment and Trade for Development, Geneva: United Nations Publications, http://unctad.org/en/ PublicationsLibrary/wir2013_en.pdf (accessed February 10, 2016).

United Nations Economic Commission for Europe (UNECE), 2015, A Guide to Measuring Global Production, Geneva: United Nations Publications, http:// www.unece.org/fileadmin/DAM/stats/publications/2015/ECE_CES_38.pdf (accessed February 12, 2016).

Van Ark, Bart, Vivian Chen, Bert Colijn, Kirsten Jaeger, Wim Overmeer and Marcel Timmer, 2013, "Recent Changes in Europe's Competitive Landscape and Medium-Term Perspectives: How the Sources of Demand and Supply Are Shaping Up", Economic Papers, No. 485, April, Brussels: European Commission, Directorate-General for Economic and Financial Affairs, http://ec.europa. eu/economy_finance/publications/economic_paper/2013/pdf/ecp485_en.pdf (accessed February 17, 2016).

World Economic Forum, 2012, The Shifting Geography of Global Value Chains: Implications for Developing Countries and Trade Policy, Geneva: World Economic Forum. 